\title{
Effect of Tomato Varieties on the Tomato Borer Tuta absoluta (Meyrick) (Lepidoptera: Gelechiidae) as a Main Insect Pest Attacking Tomato Plants in Damietta Governorate. \\ El-Kady, H. A.; Hagar S. S. Awadalla and Mai M. A. Eisa \\ Economic Entomology Department, Faculty of Agriculture, Damietta University
}

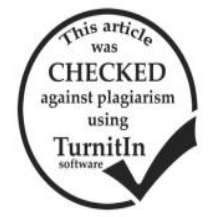

\section{ABSTRACT}

The current studies were conducted on the field at kafr El-battikh reigon, Damietta Governorate. K-186, G.S and MARRWA tomato varieties to determine the effect of different tomato varieties on the population abundance of the tomato borer Tuta absoluta (Meyrick) in February plantation during the two successive seasons 2016 and 2017. K-186 tomato variety attracted the highest average number of eggs and larvae of $T$. absoluta during the first season and represented by $265.1 \pm 45.4$ eggs and $171.7 \pm 41.8$ larvae, respectively. While G.S variety ranked the second category and represented by $238.9 \pm 40.9$ eggs and $169 \pm 41.1$ larvae, respectively. On the other hand, MARRWA variety came in the last category and represented by $183.6 \pm 45.4$ eggs and $106.9 \pm 28.6$ larvae, respectively. While during the second season G.S variety attracted the highest average number of eggs of $T$. absoluta followed by K-186 and MARRWA and represented by $281 \pm 50.7,213.5 \pm 55.7$ and $189.6 \pm 52.6$ eggs, respectively. Meanwhile, G.S variety attracted the highest average number of larvae of T. absoluta followed by MARRWA variety and K - 186 variety came in the last category and represented by $165 \pm 46.6,111.4 \pm 27.8$ and $98 \pm 21.4$ larvae, respectively. Statistical analysis revealed that a significantly differences between the tomato varieties and $T$. absoluta eggs and larvae during the two successive seasons.

Keywords: The tomato borer Tuta absoluta (Meyrick), tomato varieties

\section{INTRODUCTION}

Tomato (Lycopersicon esculentum L.), which have been turned from a fearful fruit that mankind though a toxicity to an important and indispensable component of its food. Tomatoes are one of the most important vegetable crops grown all over the world and Egypt in particular (WPTC , 2011 and Shehata et al., 2016).

Tomato crops are attacked by a lot of insect pests where all parts of the plant are a habitat, food and breeding place for many insects. The most important of these insect pests that attack tomatoes in their different stages of development are sucking piercing insects such as cotton aphid, Aphis gossypii Glov., Thrips tabaci, whiteflies and jassid, Which leads to many problems, including weakness and wilt and yellowing of plants, In addition to the secretion of some of these insects honey due causing the growth of the pathogens such as fungi and molds, and it hinders breathing and affects the photosynthesis (Awadalla, 1980; Elsayed, 2000 and Khuhro, 2014).

The tomato borer Tuta absoluta (Meyrick) (Lepidoptera: Gelechiidae) is one of the most important and most dangerous tomato pests, which larvae feed all parts of the plant leaves, fruits, branches, stems and flowers so this destruction resulting in loss of yield, which reaches 100\%.(Ramireze et al. 2010 and Lazgeen et al. 2013).Tomato borer Tuta absoluta consider the main insect that attacking tomato crops (Youssef, 2015).

The different varieties affect on tomatoes infestation with different insect pests where varieties vary in its sensitivity, resistance and tolerance to infestation (Abou-Ghadir, 2015 and Ata and Megahed, 2014).

Therefore, the current experiments were carried out to study the Effect of tomato varieties on the tomato borer Tuta absoluta (Meyrick) (Lepidoptera: Gelechiidae) as a main insect pest attacking tomato plants in Damietta Governorate.

\section{MATERIALS AND METHODS}

The current studies were conducted at the field of kafr El-battikh reigon, Damietta Governorate. K-186, G.S and MARRWA tomato varieties to determine the effect of different tomato varieties on the population abundance of the tomato borer Tuta absoluta (Meyr.) in February plantation during the two successive seasons 2016 and 2017.

The K-186, G.S and MARRWA tomato varieties were planted in (beginning of February) during the two successive seasons 2016/17 and 2017/18. An area of about $624 \mathrm{~m}^{2}$ was divided into 12 replicates, each of variety planted in four replicates and arranged in completely randomized design. The normal agriculture practices were used without any insecticidal treatments during the two successive seasons.

To estimate the population abundance of $T$. absoluta (eggs and larvae), weekly leaf samples of 25 leaves which representing the upper, middle and lower levels of the plants where chosen randomly from each replicate (100 leaves from each tomato variety ). The collected samples were transferred into plastic bags to the laboratory for examination. The number of insects was recorded by aid of lens $4 \mathrm{x}$ and a stereo microscope. Samples were taken after about three to four weeks from transplantation and extended until the harvest time. T. absoluta (eggs and larvae) were recorded and counting for each tomato variety.

The results obtained were analyzed using oneway ANOVA, and to compare means $(\alpha=0.05)$ using Duncan' s Multiple Range Test. Costat application program was used to analysis (Costat 2004).

\section{RESULTS AND DISCUSSION}

Data illustrated in Table (1) showed that that the population abundance of $T$. absoluta in three tomato varieties during the first season 2016. Showed that, K186 variety recorded the highest peak of eggs and larvae in first week of April and last week of May and represented by 546 eggs and 473 larvae, respectively. While G.S variety recorded the highest peak of eggs and 
larvae in the last week of May and represented by 493 eggs and 442 larvae, respectively. Moreover, MARRWA variety recorded the highest peak of eggs and larvae in the last week of May and represented by 598 eggs and 311 larvae, respectively.

Table 1. Effect of different tomato varieties on the population abundance of $T$. absoluta eggs and larvae during the first season $2016 / 17$ at Kafr-El battikh region.

\begin{tabular}{|c|c|c|c|c|c|c|}
\hline \multirow{2}{*}{$\begin{array}{l}\text { Sampling } \\
\text { dates }\end{array}$} & \multicolumn{3}{|c|}{ Eggs } & \multicolumn{3}{|c|}{ Larvae } \\
\hline & K-186 & G.S & MARRWA & K-186 & G.S & MARRWA \\
\hline February,29 & 0 & 12 & 0 & 3 & 16 & 0 \\
\hline March,7 & 20 & 18 & 12 & 40 & 40 & 25 \\
\hline 14 & 47 & 40 & 16 & 42 & 11 & 36 \\
\hline 21 & 222 & 123 & 29 & 112 & 113 & 37 \\
\hline 28 & 281 & 285 & 184 & 122 & 125 & 131 \\
\hline April,4 & 546 & 271 & 191 & 98 & 97 & 73 \\
\hline 11 & 298 & 297 & 223 & 84 & 86 & 76 \\
\hline 18 & 292 & 290 & 147 & 72 & 73 & 114 \\
\hline 25 & 178 & 173 & 136 & 90 & 91 & 42 \\
\hline$\overline{\text { May,2 }}$ & 224 & 224 & 165 & 370 & 374 & 67 \\
\hline 09 & 270 & 276 & 153 & 328 & 329 & 186 \\
\hline 16 & 370 & 371 & 256 & 144 & 143 & 191 \\
\hline 23 & 472 & 472 & 460 & 426 & 426 & 208 \\
\hline 30 & 491 & 493 & 598 & 473 & 442 & 311 \\
\hline Total & 3711 & 3345 & 2570 & 2404 & 2366 & 1497 \\
\hline $\operatorname{Mean} \pm \mathrm{SE}$ & $265.1 \pm 45.4$ & $238.9 \pm 40.9 \mathrm{a}$ & $183.6 \pm 45.4 \mathrm{~b}$ & $171.7 \pm 41.8$ & $169 \pm 41.1 \mathrm{a}$ & $106.9 \pm 28.6 \mathrm{~b}$ \\
\hline
\end{tabular}

Means followed by the same letters for each stage are not significantly differences at 0.05level (Duncan's Multiple Range Test).

Data illustrated in Table (2) showed that that the population abundance of $T$. absoluta in three tomato varieties during the second season 2017.showed that, K186 tomato variety recorded the highest peak of eggs and larvae in the last week of May and represented by 726 eggs and 252 larvae, respectively. While G.S variety recorded the highest peak of eggs in the first week of May and the highest peak of larvae in the last week of May and represented by 585 eggs and 470 larvae, respectively. Moreover, MARRWA variety recorded the highest peak of eggs and larvae in the last week of May and represented by 643eggs and 329 larvae, respectively.

As a conclusion, data arranged in Tables (1 and 2) indicated that, K-186 tomato variety attracted the highest average number of eggs and larvae of $T$. absoluta during the first season and represented by $265.1 \pm 45.4$ eggs and
$171.7 \pm 41.8$ larvae, respectively. While G.S variety ranked the second category and represented by $238.9 \pm 40.9$ eggs and $169 \pm 41.1$ and larvae, respectively. On the other hand, MARRWA variety came in the last category and represented by $183.6 \pm 45.4$ eggs and $106.9 \pm 28.6$ larvae, respectively. While during the second season G.S variety attracted the highest average number of eggs of T. absoluta followed by K-186 and MARRWA and represented by $281 \pm 50.7,213.5 \pm 55.7$ and $189.6 \pm 52.6$ eggs, respectively. Meanwhile, G.S variety attracted the highest average number of larvae of $T$. absoluta followed by MARRWA variety and K -186 variety came in the last category and represented by $165 \pm 46.6,111.4 \pm 27.8$ and $98 \pm 21.4$ larvae, respectively. Statistical analysis revealed that a significantly differences between the tomato varieties and $T$. absoluta during the two successive seasons.

Table 2. Effect of different tomato varieties on the population abundance of $T$. absoluta eggs and larvae during the second season $2017 / 18$ at Kafr-El battikh region.

\begin{tabular}{lcccccc}
\hline Sampling & \multicolumn{3}{c}{ Eggs } & \multicolumn{3}{c}{ Larvae } \\
\cline { 2 - 7 } dates & K-186 & G.S & MARRWA & K-186 & G.S & MARRWA \\
\hline February,29 & 0 & 0 & 0 & 16 & 13 & 14 \\
\hline March,7 & 0 & 11 & 13 & 26 & 25 & 34 \\
14 & 20 & 32 & 25 & 32 & 32 & 38 \\
21 & 67 & 297 & 37 & 34 & 18 & 47 \\
28 & 320 & 263 & 153 & 120 & 137 & 109 \\
\hline April,4 & 258 & 271 & 240 & 64 & 92 & 76 \\
11 & 252 & 138 & 198 & 82 & 63 & 43 \\
18 & 104 & 287 & 67 & 38 & 53 & 32 \\
25 & 164 & 364 & 107 & 44 & 57 & 36 \\
\hline May,2 & 174 & 585 & 193 & 74 & 136 & 83 \\
09 & 146 & 223 & 181 & 176 & 344 & 223 \\
16 & 204 & 467 & 216 & 202 & 418 & 243 \\
23 & 554 & 483 & 582 & 212 & 452 & 253 \\
30 & 726 & 513 & 643 & 252 & 470 & 329 \\
\hline Total & 2989 & 3934 & 2655 & 1372 & 2310 & 1560 \\
Mean \pm SE & $213.5 \pm 55.7$ ab & $281 \pm 50.7 \mathrm{a}$ & $189.6 \pm 52.6 \mathrm{~b}$ & $98 \pm 21.4 \mathrm{~b}$ & $165 \pm 46.6 \mathrm{a}$ & $111.4 \pm 27.8 \mathrm{~b}$ \\
\hline Means followyyyyyyyyyyyy
\end{tabular}

Means followed by the same letters for each stage are not significantly differences at 0.05level (Duncan's Multiple Range Test). 
These results are in agreement with those of Ata and Megahed (2014) in Egypt, showed significant differences in number of mines/leaf and number of larvae/leaf on the two tomato varieties. The mean number of $T$. absoluta larvae/leaf was 3.3 and 2.8 in Alisa and H.S.S varieties respectively. While the general mean numbers of T. absoluta mines/leaf was 5.5 and 4.0 in Alisa and H.S.S varieties, respectively.AbouGhadir (2015) in Egypt, showed that T. absoluta recorded different states of preference towards the investigated tomato host plants. The tomato "TH99806" was more favorable than "TH99807" on the winter season, whilst E448 was the favorite on summer season over Super Jakal, all over the observed period of 2012 and 2013. Shehata et al. (2016) in Egypt, showed that the native strain was more susceptible to infestation with $T$. absoluta, where the total number of eggs around the rotation was $5.93 \pm 5.5 \mathrm{eggs} / \mathrm{leaf}$ being significantly higher as compared to GS and super hybrid, while the total number of eggs around the cycle or the rotation in both GS and super hybrid was $8.03 \pm 1.5$ and $8.62 \pm 3.4$ eggs/leaf, respectively. Also they showed that the native strain is more susceptible to infestation with larvae where the total number of larvae around the rotation was $16.78 \pm 5.7$ larvae/leaf compared to $5.73 \pm 1.9$ and $8.5 \pm 2$ larvae/leaf in both GS and super hybrid, respectively.

\section{REFERENCES}

Abou-Ghadir, Nesreen M. F. ; Enas G. A. El-Sayed ; M. M. A. Rizk and M. A. A. Abdel-Rahman (2015):The Relative Susceptibility of Certain Tomato Hybrids to the Moth Tuta absoluta (TLM), With Reference to the Role of Plant Age on the Level of Infestation. Assiut J. Agric. Sci., 46 (1): 24-33.

Ata, T. E. and M. M. M. Megahed (2014): Population Density of Tomato Leafminer Tuta absoluta (Meyrick) (Lepidoptera : Gelechiidae) under Protected Cultivation in Egypt. Middle East Journal of Agriculture Research, 3(4): 12421247.
Awadalla, S. S. (1980): Studies on insect pests infesting tomato in Dakahlia Governorate. Unpuplished .M.Sc. Thesis, Fac. Agric. Mans. Univ., 141 pp.

CoHort Software (2004): Costat. www.cohort.com. Monterey, California,USA.

EI-Sayed, Azza A. A. (2000): Development Of An Integrated Pest Management Programme For Certain Vegetable Crops In Newly Reclaimed Land. Published Ph.D. Thesis. Fac. Agri., Ain Shams Univ.283pp.

Khuhro, S. A. ; A. Solang and A. Lanjar (2014): Surveillance on the Sucking Insect Pests and their Natural Enemies on Tomato Crop. Advances in Life Science and Technology.20: 2224-7181.

Lazgeen, H. A. ; R. H. Feyroz ; R. I. Halgurd and A. S. Salah (2013): Population Density of Tomato leaf miner Tuta absoluta Meyrick (Lepidoptera: Gelechiidae) under plastic houses conditions. $J$. Agri. and Veteri. Sci., 5(4), 07-10.

Ramirez, L ; N. Ramirez;L. S. Fuentes ;J. Jiminez and J. Hernandez - Fernandez(2010): Estandarización de un bioensayo yevaluación preliminar de tres formulaciones comerciales de Bacillus thuringiensis sobre Tuta absoluta (Meyrick) (Lepidoptera: Gelechiidae). Rev. Colomb. Biotecnol., 12(1), 12-21.

Shehata I.; I. Ebada ; I. A. Ismail ; M. Fouda and H. S. Salama (2016): On the Population Dynamics of the Tomato Leaf Miner Tuta absoluta (Meyrick) (Lepidoptera: Gelechiidae) in Egypt. Ecologia Balkanica, 8(2): 65-75.

WPTC. (2011): Report of World Processing Tomato Council. $10 \mathrm{pp}$.

Youssef, Narmen A. (2015): Ecological studyon three major insect pests of tomato plantations in fayoum governorate. Fayoum J. Agric. Res. \& Dev., 31(2)1-16.

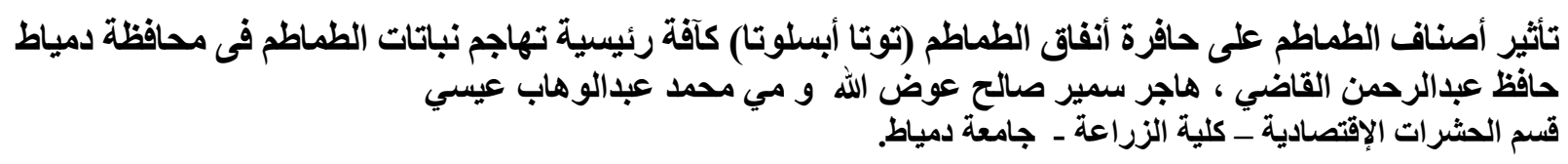

أجريت الدر اسات الحالية فى حقل في منطقة كفر البطيخ بمحافظة دمياط .حيث تمت زر اعة أصناف الطماطم

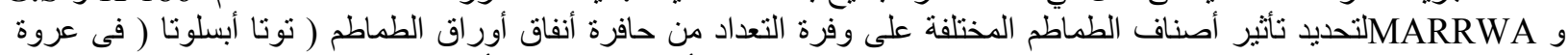

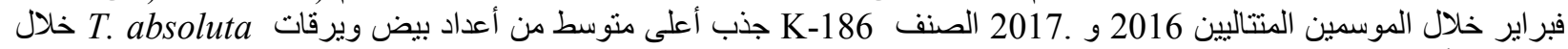

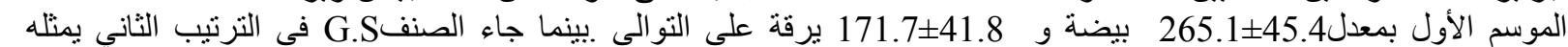

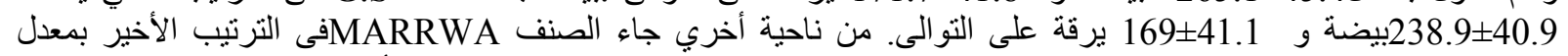

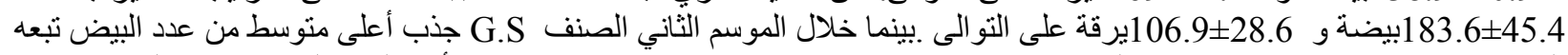
الصنف 186 KARRWA يمثلهم

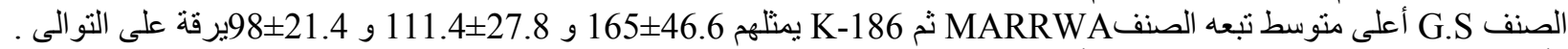
و أوضحت النتائج و جود فروق معنوية بين أصناف الطماطم و Tuta absoluta خلال الموسمين المتتايين . 